УДК 811.11

DOI https://doi.org/10.26661/2414-1135-2021-82-21

\title{
ВИКОРИСТАННЯ КЕЙС-МЕТОДУ В КОНТЕКСТІ ІНШОМОВНОЇ ПРОФЕСІЙНОЇ КОМУНІКАЦІЇ
}

\author{
Макухіна C. B. \\ старший викладач кафедри готельно-ресторанного \\ та туристичного бізнесу й іноземних мов \\ Херсонський держсавний аграрно-економічний університет \\ вул. Стрітенська, 23, Херсон, Україна \\ orcid.org/0000-0001-6269-8406 \\ makukhina.svetlana@gmail.com
}

Ключові слова: критичне мислення, проблемна ситуачія, інтерактивний метод, мотивачія, професійно орієнтоване навчання.
Розвиток сучасних технологій зумовлюе зміну підходу щодо вивчення іноземної мови в немовному закладі вищої освіти. Стаття присвячена аналізу використання методу кейс-стаді для навчання іноземної мови професійного спрямування. У роботі представлено теоретичний матеріал про метод кейс-стаді, наведено практичні рекомендації з використання цієї методики. Визначено, що, на відміну від традиційних методів сучасного викладання, метод кейс-стаді потребує активної участі здобувача вищої освіти в процесі навчання. Кейси дають змогу здобувачам творчо застосовувати пройдений мовний матеріал на базі своїх професійних знань і адаптуватися до реальних і потенційно можливих ситуацій, розвивають вміння вести дискусію, вдосконалюють навички професійного читання іноземною мовою, дають змогу повноцінно вирішити самостійну роботу здобувачів. У статті наголошено на формуванні конкурентоздатності в процесі роботи над ситуаціями у здобувачів, розвитку персональної і колективної відповідальності, особистих цінностей та установок, здобуванні навичок управління репутацією і формуванні позитивного іміджу. Розглянуто моделі ситуаційного навчання, виділено етапи створення кейсу, які допомагають зробити навчання більш результативним і ефективним. Проаналізовано переваги, недоліки і особливості застосування кейс-стаді як активного методу навчання іноземних мов, принципи і закономірності критичного мислення, основні психолого-педагогічної характеристики здобувачів в освітньому процесі аграрно-економічних закладів вищої освіти. На базі аналізу теоретичних джерел та педагогічної практики пропонується напрям пошуку більш продуктивних підходів та способів вирішення питання розвитку проблемно-дієвої основи навчання професійній англійській мові в контексті впровадження кейс-методу. Розвиток цього методу - це динамічний та циклічний процес, який передбачає постійну взаємодію між афективними, когнітивними та експериментальними факторами. Зроблено висновки, що кейси та рольові ігри, які розглядають проблемні ситуації реального бізнесу, мотивують студентів-аграріїв вивчати іноземну мову i застосовувати на практиці свої професійні знання. 


\title{
THE USE OF CASE-STUDY METHOD IN THE CONTEXT OF FOREIGN LANGUAGE PROFESSIONAL COMMUNICATION
}

\author{
Makukhina S. V. \\ Senior Lecturer at the Department of Hotel and Restaurant \\ and Tourism Business and Foreign Languages \\ Kherson State Agrarian and Economic University \\ Stritenska str., 23, Kherson, Ukraine \\ orcid.org/0000-0001-6269-8406 \\ makukhina.svetlana@gmail.com
}

Key words: critical thinking, problem situation, interactive method, motivation, professionally-oriented teaching.
The development of modern technologies leads to a change in the approach to learning a foreign language in a non-language institution of higher education. Case-study is one of the active learning approaches considered as a more effective way to develop professional skills and achieve learning outcomes than traditional teaching methods. The article is dedicated to the analysis of the application of the case-study method for professionaloriented foreign language training. The article presents theoretical material on the case study method, provides practical recommendations. Case method requires the active participation of the applicant in higher education. Cases allow to apply language teaching material on the professional knowledge basis and adapt to real and potential situations, develop the ability to lead a discussion, improve professional reading skills in a foreign language. The article emphasizes the formation of competitiveness in the process of applicants' work on situations, the development of individual and collective responsibility, personal values and attitudes, the acquisition of reputation management skills and the formation of a positive image. The article discusses situational learning models, stages of effective case creative training. It is spoken about the advantages, disadvantages and features of case study as an active method of foreign languages training, principles and patterns of critical thinking, the main psychological and pedagogical characteristics of applicants in the educational process of agricultural and economic institutions of higher education. The case technology is actively used by foreign language teachers in teaching training and get the educational process to apply in the real life, thus motivating the students. It is argued that the development of new teaching routines is a dynamic, cyclical and dialectic process which involves ongoing interaction between affective, cognitive, contextual and experiential factors. It is concluded that cases and role-playing games that consider problematic situations of real business motivate agricultural students to learn a foreign language and apply their professional knowledge in practice.
Постановка проблеми. У системі вищої професійної освіти важливим $є$ формування набору базових компетенцій, передача універсальних способів діяльності, норм і правил, здійснення професійної діяльності, формування уявлень про устрій сфер діяльності, необхідність розвитку особистості здобувача призводять до зміни вимог до особистості фахівця, його здатності виконувати інтелектуальні роботи та вміння вбудовуватися в ті чи інші сфери діяльності.

Мета i завдання статті. Мета цієї статті - вивчити потенціал методу кейс-стаді в процесі навчання іноземної мови професійного спрямування, дослідити використання методу кейсів шляхом формування іншомовної компетентності у здобувачів вищої освіти, що вивчають іноземну мову за фахом.

Предмет та об'єкт дослідження. Предметом цього дослідження $\epsilon$ кейс технології як засіб формування іншомовної професійної комунікації, об'єктом є навчання іноземної мови студентів аграрних закладів вищої освіти.

Виклад основного матеріалу дослідження. Сучасний ринок праці висуває певні вимоги щодо володіння мовами міжнародного спілкування. У суспільстві зростає потреба у фахівцях, які 
володіють іншомовними професійними компетентностями, тобто навичками, необхідними для спілкування 3 іноземними колегами, вміннями розуміти чужу мову i правильно формулювати нею свої думки. Сучасний фахівець має вміти проявляти ініціативу, самостійність, розвиватися творчо і професійно. Критерієм ефективності системи освіти стає те, наскільки ця система виконує соціальне замовлення суспільства.

Концепція комунікації $є$ метою i засобом навчання взаємодії фахівців у професійній діяльності, які мають підвищувати свою комунікативну компетентність, знати форми і методи впливу на опонентів або співрозмовників, тобто вдосконалювати культуру спілкування.

Кейс-метод може бути успішно використаний на заняттях з іноземної мови, оскільки цей метод комплексний і містить всі види мовленнєвої діяльності: читання, говоріння, письмо, аудіювання. У здобувачів 3'являється реальна можливість спілкування іноземною мовою в процесі взаємодії з іншими учасниками групи і викладачем. Успіх кейс-методу залежить від трьох основних складників: якості кейса, підготовленості здобувачів і готовності самого викладача до організації роботи 3 кейсом і ведення дискусії.

Отже, ефективним методом є залучення здобувача вищої освіти в професійне мовне середовище одночасно 3 навчанням у комунікативній мовній групі. Іноземна мова в цьому разі виступає не як окремий предмет навчання, а як необхідний допоміжний елемент і провідник у багаторівневій системі навчання, як засіб розвитку комунікативних умінь і навичок у процесі здійснення здобувачами професійної дослідницької діяльності за допомогою інформаційних і комунікаційних технологій.

Окрім традиційного підходу до вивчення іноземної мови за фахом, що приділяє основну увагу розвитку навичок читання і перекладу, використовуються комунікативний і професійно орієнтований підходи. Крім традиційної роботи 3 текстом, увага приділяється i навичкам говоріння на професійну тему. У немовних вузах професійно орієнтоване спілкування іноземною мовою визначається як обмін професійно значущою інформацією, що забезпечує взаєморозуміння між партнерами по спілкуванню, тобто представниками різних професійних спільнот.

Слід зазначити, що саме кейс-технології сприяють залученню в освітній процес елементів професійної діяльності в контексті вивчення іноземних мов. Тим самим забезпечується перехід від навчальних ситуацій до професійних, де у вирішенні проблеми вимагається використання знань і відповідних компетенцій, що формуються в процесі вивчення певної дисципліни. Тому в умовах застосування кейс-технології студентам доцільно пропонувати конкретні реальні або наближені до реальної ситуації з професійної практики, які після обговорення на заняттях стануть у майбутньому основою їхньої професійної діяльності [1, с. 28].

Застосування кейс-технологій у процесі навчання полягає в тому, що засвоєння знань і формування умінь відбувається в результаті активної самостійної діяльності здобувачів із вирішення протиріч i поставлених конкретних завдань у навчальній аудиторії. Під час вирішення конкретної ситуації здобувачі використовують свій життєвий досвід і отримані знання, застосовують ті засоби і критерії аналізу, які були придбані ними в процесі попереднього навчання [2, с. 67]. Внаслідок чого і відбувається оволодіння і закріплення професійних знань, навичок, умінь і розвиток розумових і творчих здібностей.

При цьому формуються умови, в яких здобувачі:

1) набувають нові знання, застосовуючи різні ресурси, в тому числі Інтернет-джерела;

2) навчаються використовувати отримані знання $з$ метою вирішення навчальних і практичних завдань;

3) набувають комунікативне майстерність, працюючи в групах, розвивають навички говоріння;

4) формують дослідницькі вміння (вміння виявлення труднощів, збору даних, спостереження, проведення експерименту, аналізу, зведення гіпотез, узагальнення та системного мислення);

5) формують вміння інформаційного пошуку. Кейси можуть містити опис однієї події в одній організації або історію розвитку багатьох організацій за багато років і можуть бути представлені від кількох пропозицій на одній сторінці і до безлічі сторінок. Немає певного стандарту уявлення кейсів. Однак необхідно мати на увазі, що великі кейси викликають деякі труднощі під час роботи з ними.

Кейси можуть бути класифіковані з огляду на цілі і завдання процесу навчання. У цьому випадку можуть бути виділені типи кейсів, що спонукають до аналізу та оцінки, вирішення проблем і прийняття рішень, ілюстрації проблеми, рішення або концепції загалом.

Розрізнюють такі види кейсів, як практичні, що мають якомога реальніше відображати ситуацію або випадок, навчальні, основним завданням яких виступає навчання, та науково-дослідні кейси, які орієнтують здобувачів на дослідницьку діяльність.

Слід зазначити, що кожен кейс несе в собі навчальну функцію, тільки ступінь вираженості цієї функції варіюється в окремих видах кейсів по-різному.

Як правило, кейси представляються в друкованому вигляді або на електронних носіях, притому включення в текст фотографій, діаграм, таблиць робить його більш наочним і захоплюючим. Із такою інформацією легше працювати, іiі легше аналізувати, ніж інформацію, представлену, наприклад, в 
аудіо- чи відеоваріантах, коли обмежені можливості багаторазового інтерактивного перегляду, що може привести до спотворення первинної інформації i, відповідно, до подальших помилок. Останнім часом дедалі популярнішими стають мультимедіа кейси, що поєднують в собі переваги текстової інформації та інтерактивного відеозображення [3, с. 88].

Попередня робота передбачає вивчення граматики, нової лексики, ідіом, оволодіння новими синтаксичними структурами за темами бізнесу і включає такі області діяльності, як комунікація в бізнесі, міжнародний маркетинг, відносини 3 партнерами по бізнесу, успішність компанії, види ризику в бізнесі, торгівля, створення грошового фонду, обслуговування клієнтів, управління кризовими ситуаціями, стилі керівництва, майбутнє бізнесу.

Розглянемо етапи роботи 3 кейсом.

1) введення в проблему. Здобувачам пропонується кілька комунікативних ситуацій ділового спілкування. Вправи до них мають дискусійний характер. Учасникам пропонується зрозуміти умови професійної діяльності, які враховують потребу рішення проблеми. У процесі ії дозволу здобувачі мають актуалізувати потрібну для цього сукупність набутих знань. При цьому аналізується автентичне використання мови, випадки фразеології і ідіоматики, механіка обміну репліками та ін.;

2) збір інформації. Необхідно описати всіх істотних осіб, втягнутих у ситуацію, зіставити аспекти, які важливі в процесі вирішення обговорюваної проблеми, знайти і оцінити інформацію. Несподіванка ситуації і бажання вирішити проблему, як правило, спонукають студентів не просто прочитати запропонований далі кейс, але й ретельно його вивчити, опанувати факти і деталі;

3) розгляд альтернатив. На цьому етапі йде розробка різних рішень і вивчення їх альтернативних варіантів. Виконується робота з лексикою, пропонуються вправи на перефразування, використання синонімічного ряду. Здобувачі набувають навички ведення переговорів англійською мовою, розглядають способи відповіді на важкі запитання, можливості виграти час на обдумування. Учасники розглядають зразки функціональної лексики, що використовується під час переговорів;

4) прийняття рішення. Відбувається оцінка варіантів вирішення проблеми і вибирається оптимальне рішення;

5) презентація рішення. На цьому етапі здобувачі можуть апробувати свої комунікативні здібності в процесі подання рішення і аргументації вибору, отримати можливість знайти власні слабкі сторони і прагнення працювати в напрямі поліпшення мовленнєвих здібностей.

Використання методу case-study має явні переваги перед простим викладом матеріалу, широко використовуваним у традиційній педа- гогіці вищої школи України. До переваг методу case-study можна зарахувати також розвиток аналітичних, діагностичних та концептуальних здібностей студентів, вміння використовувати теоретичний матеріал на практичних прикладах, формування системи цінностей, життєвих установокздобувачів, отримання навичокроботив команді (Team Job Skills) та створення позитивного психологічного клімату в групі [4, с. 97].

До недоліків кейс-стаді можна зарахувати надмірність інформації; суб'єктивність і поверховість дослідницького підходу. Зазначимо, що в цього методу є і свої труднощі у використанні. Перш за все, необхідно багато часу для грамотної підготовки кейсу до заняття. Викладач має продумати форму подання кейсу і спланувати діяльність учнів, поєднуючи індивідуальні та групові форми роботи. Непростим моментом для викладача $€$ оцінювання, бо потрібно оцінити роботу кожного учасника, його активність і оригінальність, водночас необхідно об'єктивно оцінити його знання.

Висновки і перспективи подалыших розробок. На основі проведеного аналізу методу кейсових ситуацій вважаємо за доцільне використовувати його на практичних заняттях 3 англійської мови за професійним спрямуванням, оскільки цей метод сприяє розвитку іншомовної професійної комунікації та дає змогу здобувачу вчитися самостійно аналізувати і досліджувати конкретні ситуації, наближені до реальних умов, вміти приймати обгрунтовані і правильні рішення та покращувати свої здібності роботи як окремо, так і в малих робочих групах. Незважаючи на недоліки кейс-методу, зокрема складну роботу з розробки й оновлення кейсових ситуацій, переваг у нього більше.

\section{ЛІТЕРАТУРА}

1. Гребенькова Г.В. Кейс-метод у професійному навчанні. URL: http://www.nmc.od.ua/ wpcontent/uploads/2011/01/ (дата звернення 26.02.2020).

2. Інноваційні технології навчання в діяльності інженера-педагога: навчальний посібник для інженера-педагога: у 2 ч. / [Коваленко О.Е., Штефан Л.В., Лисенко С.А., та ін.]; за ред. О.Е. Коваленко, Л.В. Штефан. Харків : Вид-во ТОВ «Цифрова друкарня № 1», 2013. Ч. 1 : Теоретичні основи. $195 \mathrm{c}$.

3. Ожегова Л.А. Метод case studies как эффективная форма обучения студентов географических спеціальностей. Ученые записки Таврического национального университета им. В.И. Вернадского. Серия «География». Том 25 (64). 2012. № 4. С. 87-96.

4. Ситуаційна методика навчання: теорія і практика / Упор. О. Сидоренко, В. Чуба. Київ, 2001. $256 \mathrm{c}$. 


\section{REFERENCES}

1. Grebenkova, G.V. (2011) Kejs-metod u profesijnomu navchanni [Keys-method in professional education]. URL: http://www.nmc.od.ua/ wpcontent/uploads/ (accessed 26 February 2020)

2. Innovatsiyni tekhnolohiyi navchannya $\mathrm{v}$ diyal'nosti inzhenera-pedahoha: navchal'nyy posibnyk dlya inzhenera-pedahoha: u 2 ch. (2013) / [Kovalenko O.E., Shtefan L.V., Lysenko S.A., ta in.]; za red. O.E. Kovalenko, L.V. Shtefan. [Innovational technologies of education in engineer-teacher activity]: Kharkiv: Vyd-vo TOV «Tsyfrova drukarnya №1», CH. 1 : Teoretychni osnovy. 195 c. (in Ukrainian).
3. Ozhegova, L.A. (2012) Metod case studies kak effektivnaya forma obucheniya studentov geograficheskikh specialnostey. [Keys-method as an effective form of student's education of geographical specialties] Uchyonye zapiski Tavricheskogo natsionalnogo universiteta im. V.Y. Vernadskogo. [Scholarly notes of the Vernadsky Tavricheskiy National University] Seriya «Geografiya». Tom 25 (64). № 4. Pp. 87-96. (in Russian).

4. Sydorenko, O. Chuba, V. (2001) Sytuacijna metodyka navchannja: teorija i praktyka [Situational training of education: theory and practice.] Kyiv: Tsentr innovatsiy ta rozvytku, p. 256. (in Ukrainian). 